\title{
Thoughts on the Dilemma of When to Introduce the Euro in Hungary*
}

\author{
Péter Gottfried
}

In its EU accession treaty, Hungary committed to introducing the euro without a legally binding deadline. The question is therefore not whether the country will introduce the common currency, but when it will do so, and what factors play a role in the decision. Developments in recent years have confirmed that the euro system is able to weather a crisis, but also highlight that the euro does not in itself guarantee sustainable convergence. In addition to accession, members' rights and obligations have also changed considerably, and these changes have not been completed. There are examples for successful economic policies without the euro and also for frustrated growth with the euro. Only one area has been identified where the advantages of membership are indisputable: yield spreads. In today's international environment, this is much less important than in the past, but it is impossible to know how long this situation will last. Accordingly, the Hungarian strategy should target sustainable convergence, rather than the introduction of the euro. If the country can substantially reverse the increase in the government deficit and debt and keep them low, it would be worth waiting until the development paths related to the euro are outlined more clearly, while continuing with convergence. If this is not possible, the option to join the euro area as soon as possible should be preferred, which offers greater security but less room for autonomous manoeuvre.

Journal of Economic Literature (JEL) codes: E58, F36, F42, F45, H63, N14, N24, N44, N90, N94, O40, O52, O57, P43

Keywords: EU, euro area, EMU, euro, European integration

\section{Introduction}

In its Treaty of Accession to the European Union, ${ }^{1}$ Hungary undertook to strive to establish the conditions for introducing the euro and initiate its use when the time is right. This commitment will mark its 20th anniversary in 2022, as the accession talks ended in 2002.

\footnotetext{
* The papers in this issue contain the views of the authors which are not necessarily the same as the official views of the Magyar Nemzeti Bank.

Péter Gottfried is a Member of the Monetary Council. Email: gottfriedp@mnb.hu

The Hungarian manuscript was received on 29 May 2021.
}

DOI: http://doi.org/10.33893/FER.20.3.110126

${ }^{1}$ Promulgated by Act XXX of 2004, entered into force on 1 May 2004. The negotiations were concluded at the Intergovernmental Conference tied to a meeting of the European Council in Copenhagen in December 2002. 
The legal situation is straightforward. In recent years, the Hungarian public has passively acknowledged the timing of joining the euro area. Opinion polls show ${ }^{2}$ that the Hungarian public has a generally positive attitude towards introducing the euro at some point. The government also assumes that it will happen if the conditions are right. Nevertheless, the exact conditions and parameters that have any relevance to a future decision, including the timeframe in which the Hungarian euro can be expected, seem to be less "settled". The question now is not whether the euro will become the Hungarian currency, but under what conditions and in what timeframe this should be expected.

During the past almost two decades, there were periods when a concrete target date was set. In the first decade, the "obscure object of desire" was determined several times, and in the end, following several necessary postponements, what stuck in people's minds was something like "we are always five years away" from introducing the euro. In the second decade, Hungary's perspective changed. In light of the euro area crisis following the global economic meltdown, introducing the euro started to be seen in a more nuanced manner. Experts and policymakers no longer ask when Hungary will become "worthy" of joining, but whether it is "good for the country", and if so, when Hungary should join.

Until recently, no meaningful debate occurred on the aspect that the single currency cannot in itself be deemed useful or harmful from the perspective of a country already using it or one on the brink of joining the currency club, without analysing competitiveness. Likewise, no major objection was heard from experts to the approach that appropriate competitiveness can be captured as about 8590 per cent of GDP per capita at purchasing power parity (today this indicator is at approximately 73 per cent). This argument is partly based on the fact that experience has shown that hurriedly joining the currency area due to political pressure sooner or later poses problems, first to the country joining the club, and soon perhaps even to its partners that are already members. Joining the currency bloc is intended to provide extra resources to Hungary and to its partners, rather than cause a headache for anyone. This is probably the reason why Hungary's partners within the euro area are not pushing for those still outside the bloc to join. (Apart from some brief efforts, such as when the Juncker Commission, in its draft budget for 2020-2027, referred to its idea about technical assistance as an "irresistible offer". Of course, it is the responsibility of the aspiring member to provide the necessary conditions and to take the legal initiative, and those in the currency club accept the bid if the conditions are deemed to have been met.)

\footnotetext{
${ }^{2}$ See the Eurobarometer survey from October 2019, in which 66 per cent of Hungarian respondents were positive towards the euro: https://www.gesis.org/en/eurobarometer-data-service/survey-series/standardspecial-eb/study-overview/eurobarometer-922-za7580-october-2019
} 
Shifting the focus slightly, this paper does not examine when and how Hungary can become able to introduce the euro, but rather merely highlights some considerations in the following areas:

- the extent to which the countries that already use the euro and the system as a whole have met the expectations;

- the possible development paths for the system;

- and the conclusions that can be drawn from this regarding the timing of Hungary's euro accession.

The author raises some future questions that are relevant for Hungary. The past and the present are mentioned only to the extent they are considered important from the perspective of the future when assuming trends. The aim is not to comment on earlier decisions, but to provide input for a solid vision.

\section{Change and stability}

Much has changed in the past two decades - or three, if one starts counting from the birth of the concept of the euro. These changes are important for at least three reasons.

First: the economic and theoretical framework of the single currency area has changed. ${ }^{3}$ One need only recall the unbelievably rapid transformation that has occurred between the economic policy management of the euro area crisis following the 2008-2009 meltdown and today's pandemic crisis management. Of course, the nature of the two crises is different, just as the nature of the vicious sovereign-bank-corporate debt triangle and economic policy priorities have also undeniably changed. Suffice it to mention the statements in which the key figures of the earlier crisis management, the members of the "troika", warned the world about returning to normalcy too early. Let us not forget, today's situation is characterised by quantitative easing, the suspension of deficit and debt rules, and the easing of public support rules. Much has changed in the tone since the times when the recipe of the EU/ECB/IMF bailout packages was to guide distressed countries towards balance through fiscal austerity. ${ }^{4}$

Second: the situation within the euro area has changed. The initial unbridled optimism was tempered by the fact that while the system proved to be resilient to crises, not much has been achieved in terms of the main objective. The downward trend in the share of the EU and the euro area within the global economy and

\footnotetext{
${ }^{3}$ This was already discussed in the 1990s; see, for example, Bordo-Jonung (1997).

${ }^{4}$ Press conference by Christine Lagarde following the meeting of the ECB's Governing Council on 11 March 2021.
} 
world trade has not stopped, and no convergence within the euro area has been accomplished (see, for example, Bongardt et al. 2013). Experiences differ, not only in the case of newcomers, but also of the founders. There were failed attempts to eliminate the structural factors that regenerate the balance of trade and balance of payments surpluses and deficits within the euro area and that broaden the gap between the northern and southern parts of the bloc in terms of GDP per capita, rather than narrowing it. The political necessities arising from this lead to forced compromises and contingency solutions; see, for example, the joint borrowing, which was planned to be a one-off. In general, the acceptance and diffusion of responsibility has separated members into groups that are permanently at loggerheads (Acocella 2020).

Third: the considerations of EU members not currently using the euro have also changed. Brexit has significantly reduced the ability of this country group to promote their interests. The group already using the euro has ample voting power to decide the overwhelming majority of questions within the European Union, even in issues unrelated to the euro. At the same time, on average the EU-27 performs better in most real economy indicators (growth, employment, balance indicators) than the euro area. In other words, joining the bloc confers no special prestige if it is not warranted by a sensible cost-benefit calculation. This can be based on others' experiences, but the factors involved are so wide-ranging that they should be treated carefully, considering the features of the country concerned. ${ }^{5}$

While there are huge changes, the geopolitical considerations are largely unaffected and stable. Hungary's geopolitical stance and links to alliances were set in stone by the EU and NATO accession. It follows from this that joining the euro area does not bring about change from this perspective.

Undoubtedly, in the given moment, the democratically elected leaders made all the past decisions considered the best, based on the advice from the best possible experts. The only goal here is to contribute to a discussion that serves this purpose under the new conditions. One thing is certain. The success of the euro area is in Hungary's best interest, whether Hungary is outside it or inside it. Despite being a non-euro area member, Hungary's trade and economic integration with the club is among the highest and is higher than in the case of most members within the bloc. Therefore, the country should probably continue to refrain from interfering with the solutions to the current problems, and to hope for success, because Hungary has a vested interest in that. On the other hand, the country should offer and defend its opinion on the issues pertaining to the future. This essay intends to highlight some political, geostrategic, integration policy and economic issues, before drawing conclusions from them.

\footnotetext{
${ }^{5}$ Eurostat annual national accounts
} 


\section{Where is the euro area now? Political, geostrategic and European policy considerations}

The creation of the common currency is perhaps the greatest achievement of European integration so far. Just as European integration itself is a political project implemented with economic instruments, the euro is one, too.

For many centuries, European politics and history were characterised by the search for balance. The decision on European integration, produced by deeply political ideas following the Second World War, was a response to this search for balance: some kind of balance between European powers seemed to emerge for a few decades from time to time, but it was always undermined. These periods of balance were times of peace, while the disruption of and renewed search for balance meant wars in Europe. The "founding fathers" wanted the national powers that formed the basis for the defence industry at that time, such as the coal and steel industry, to be jointly exercised by the participating nations, especially Germany and France. In effect, the establishment of the European Coal and Steel Community was to serve as a check on building capacities that could have been used against each other. (Let us not consider the issue to what extent this idea was inspired by Americans, which would be difficult to clarify today anyway.) In other words, the limited customs union that emerged, the quotas and other economic instruments served a political purpose.

Similarly, the idea of creating the euro was based on political considerations. The fall of the Iron Curtain and the imminent prospect of German reunification and the slightly more distant perspective of uniting Europe once again raised the issue of the European balance of power. In particular, it led to the French concern that the new conditions may lead to German dominance, which would jeopardise the newfound stability, based on the assumption that Germany's presence in the Central and Eastern European region would become more intensive. The French wanted guarantees that this would not upset the balance. The common currency was to serve this purpose and to be a condition that ensures, like a steel hoop on barrel, enduring cohesion under the new conditions, at least in Franco-German relations.

Although it concerned a country that had not introduced the euro, Brexit brought about important changes in European political relations, at several levels and to an extent that cannot be accurately measured yet. The exit of a permanent member of the UN Security Council, a G7 member and a nuclear power dramatically reduces the EU's global power and also affects the power relations within Europe. Beyond the immediate effects, for Hungary the indirect consequences - arising from the fact that the balance between economic philosophies has been undermined may be even more important. In the face of the continental French and German thinking not wary of greater state engagement restricting, or at least regulating, 
competition, the group comprising the Netherlands, Nordic and Baltic countries and the Visegrád Group ${ }^{6}$, headed by the UK and favouring free trade relations, as free competition as possible and limited state intervention, was a balancing factor. This balance seems to have been disturbed in the absence of the UK. The so-called New Hanseatic League led by the Netherlands is making some efforts, but the coordination and influence of the German-French-southern group seems to be increasing. At the same time, difficult compromises need to be forged in issues, such as the appropriate ratio of preventing and sharing financial risks or the method and extent of solidarity.

\section{The euro is a work in progress}

The current structure of the euro area is still a work in progress. Although it has proved to be more resilient to crises than many people had thought, having withstood the debt crisis, and it also seems to be weathering the pandemic crisis well, there is a widespread argument that the structure cannot be sustained for long at its present state of completion. A step needs to be taken, either backwards or forwards. However, neither of these steps are easy (Erhart 2021). Taking a step backwards would cause incalculable political and material losses. This is attested by Mario Draghi's famous "Whatever it takes" speech" and the approximately EUR 280 billion spent on various Greek bailout packages so far. It seems that despite the expectations about dissolution of the euro area, the disintegration of the system or an exit by individual members, even temporarily, are politically unrealistic. Therefore, a step needs to be taken forwards to stabilise the structure. But this is also not simple or free of contradictions. Recent years have seen major steps that could assist in crisis management without taking a significant leap in the most critical issue, namely the new ratio of risk prevention and dispersion. While one group, let us call it the north-western school, cites individual responsibility, the other one, let us refer to it as the Mediterranean school, cites solidarity. A large portion of the instruments and institutions have been established that could be created without changing the frontlines. The banking union has been set up, with the exception of common deposit insurance, and the European Stability Mechanism (ESM), and thus also the intricate system of backstops, has received an extended mandate. However, attempts to venture beyond this red line, towards a fiscal union, have always failed. On account of the dilemmas about the future and also because Hungary was directly concerned, it is important to note that the plan to create a separate, albeit not too large, part within the EU-27's budget for euro area

\footnotetext{
${ }^{6}$ Visegrád Group or V4 Group: Czechia, Hungary, Poland and Slovakia

${ }^{7}$ Mario Draghi's speech at the Global Investment Conference in London on 26 July 2012.
} 
members, which would have mainly had theoretical significance, failed to succeed. This was replaced by the Reconstruction Fund for the EU-27. ${ }^{8}$

In this respect, special attention should be paid to the European Reconstruction Fund.$^{9}$ It is, on the one hand, a significant step as regards debt or a future part of that, as after a long "frugal" resistance, in the end, common bond issues take place (when the Commission appears on the market as a borrower, while the guarantee is provided jointly by the Member States). On the other hand, this operation comes with the condition for Member States and institutions that it is one-off which does not create a precedent for the future. Taking into account that the debate was intense even without the pandemic and that government deficits and sovereign debt increased substantially due to the national pandemic measures precisely where deficit and debt levels were already exceptionally high to begin with, the extraordinary situation was more of a pretext, and it remains to be seen whether common debt issuance can be prevented from becoming a recurring or even permanent instrument.

The aforementioned uncertainty with respect to future development paths poses a separate dilemma for countries, including Hungary. This is because the issue is complicated, in that the groups of "responsibility-takers arguing for risk reduction" and "diffusers arguing for risk sharing" do not overlap with the rich and the poor. Historical experiences and cultural traditions are just as important in countries' positions as development rankings. Ultimately, it comes down to the assessment by countries' current leaders as to what has a greater chance and importance for the country's future. Diffusing or sharing risks and ultimately responsibility in as large a community as possible, which also means that countries are less able to take responsibility for their own fate, but expect to be better off together with the others, or retaining the control over one's own fate to the necessary extent, even if it is more difficult and a greater responsibility. This is a question of deeply rooted world views. Moreover, the decision is difficult, if not impossible, to correct later on. The problem is not that if things do not go well, a euro area member cannot not leave the system at any time. The system is comprised of democratic states that abide by the rule of law. No one will be forced to join or leave the bloc against their own will. However, an exit would entail much heavier losses than what could be expected in the case of Brexit. In other words, a hasty decision can only be corrected at the price of huge losses, if at all, which can only be endured once per one, two or even more generations. So, careful, cool-headed deliberation is in order.

\footnotetext{
${ }^{8}$ Among the concepts about the EMU's reform, one should mention the so-called Five Presidents' Report, presented by the heads of the European Council, the European Commission, the European Parliament, the Eurogroup and the ECB in June 2015.

${ }^{9}$ Part of Next Generation EU is the Recovery and Resilience Facility, which provides loans of EUR 360 billion and grants of EUR 312.5 billion, EUR 672.5 billion in total, to Member States.
} 


\section{For the assessment - To what extent has the euro met or not met expectations? ${ }^{10}$}

European integration and its flagship product, the euro, have contributed to stability. Although it has been unable to halt the realignment within the global economy, i.e. the downward trend in Europe's relative importance, it has proven to be more resilient to crises than ever thought. How many times has the euro, or at least the membership of some countries, been declared doomed! It seems that in critical situations the political will has always been stronger, so that the system was able to overcome crises, even if at the price of compromises. But was it able to facilitate convergence within the bloc?

Economic convergence can be assessed from several aspects. The expectation and assumption in the 1992 Maastricht Treaty was that by introducing the euro, members would waive their monetary policy autonomy, in exchange for achieving greater stability and economic growth by eliminating the uncertainties arising from exchange rate movements and reducing borrowing and transaction costs.

In the preliminary phase of euro introduction, there was a special focus on the developments in nominal convergence. The assumption was that the prices of the goods marketed in the euro area would level off, inflation would converge, leaving some room for productivity increase in the converging members, while the rules on fiscal discipline would prevent the decentralised fiscal policies from leading to disorder with spillover effects felt in other members. The fiscal requirements were supplemented with the "no bailout" rule to underline the strictness of fiscal discipline and the inevitability of responsibility.

In itself and in theory, convergence as expressed in income per capita is not necessarily a condition for economic integration, but it is perhaps its most important political goal and promise. Increasing welfare was an express aim of the "ever closer union". According to the dominant attitude around the time when the concept of the euro was born, the elimination of exchange rate risks and obstacles diverts capital towards converging countries and regions. However, labour flows shift towards the countries with higher wages. Nevertheless, it should be recalled, partly in light of today's debates, that the risk of divergence was also taken into account, for the off chance that economic resources would concentrate in the regions that were already better supplied with human resources and infrastructure. That is why structural and cohesion policies were and still are vitally important, not only for the beneficiaries of redistribution, but also for the viability of the entire system.

\footnotetext{
${ }^{10}$ This section is based on Virág (2020) and Acocella (2020).
} 
The trends so far do not show that the introduction of the euro brought about a convergence in income levels (Franks et al. 2018). Even within the core, there is a significant difference between the high German incomes and the lower-thanaverage French wages, and especially Italian incomes, which have stagnated for about two decades. It should be noted that even within the same country, different periods may show variation. A good example for this is the period of slow growth after the introduction of the euro, followed by a rapid rise in the wake of the Hartz reforms. The performance of the countries that joined later is also not compelling evidence for the expected convergence effect. In contrast to the impressive convergence process of the Baltic states, which had a lower level of development to begin with, in Slovakia, Slovenia and Finland GDP per capita measured at purchasing power parity relative to the euro area or the EU-27 decreased rather than increased. Nonetheless, within the EU-27, there is a clear trend of the V4 Group converging rapidly, sometimes even catching up with southern cohesion countries (Tokarski 2019).

It is worth mentioning that the analyses have shown that the income convergence of the 12 founding countries slowed down after the introduction of the euro and then stopped altogether, and in fact, some divergence can also be detected. Meanwhile, on average, the countries that joined in $\mathbf{2 0 0 7}$ or later continued their convergence, although there are huge differences even within that (Alcidi 2018).

The yield advantage is straightforward in the countries using the euro. This is not so important in today's low interest rate environment, but this situation is only temporary, and it is difficult to predict how long it will last. Its importance is reflected in the fact that even though the national debt of euro area members has risen significantly, the costs of debt servicing have dropped from over 5 per cent in 1995 to 1.6 per cent today. A similar trend can be seen in Hungary as well. Prior to the pandemic, servicing a debt of around 60 per cent cost over 4 per cent of GDP, whereas in the times of the extraordinary monetary easing, a debt of approximately 80 per cent can be financed at a cost of around 2 per cent of GDP.

In theory, the convergence of economic structures is not a necessary condition for successful monetary policy, unlike the flexibility and adjustability of the labour market and goods market. The lack of these explains the recent rising efforts to coordinate and harmonise traditionally Member State policies, such as welfare systems, minimum wage setting and social security systems.

Among the indicators reflecting nominal convergence, the development of inflation rates shows that most of the reduction in differences occurred during the preparation for the euro's introduction. Until 2015, there were not very significant but quite persistent differences, and the upper band was consistently occupied by the same members (Ireland, Greece, Spain and Portugal), and these differences 
continuously undermined their competitiveness. A separate analysis is needed to determine whether the pandemic influenced this situation. During the 20082009 crisis, the convergence of inflation rates did not continue.

In terms of the convergence of business cycles, the picture is less clear. Some researchers say that the harmonisation within the euro area is greater than outside the group, but the level does not seem to increase over time. Others have found that although business cycles have become more harmonised, the size of fluctuations has increased. It follows from this that while the harmonisation of the cycles gives more chance for a successful common monetary policy, there are periods where the levels of optimal easing or tightening differ.

There were high hopes about the euro's impact on trade development and trade diversion, in other words that some of the trade with those outside the bloc would be diverted to within the euro area. Two things should be noted from a Hungarian perspective. First, the share of the EU and the euro area is so high in Hungarian exports, but also in imports, that increasing it any further is not a sensible objective. (In 2019, 80.9 per cent of Hungarian exports went to the EU (HCSO 2020), which is one of the highest proportions among Member States.) Second, interconnectedness in trade is currently experiencing a realignment, irrespective of the introduction of the euro. In 2020, Germany's volume of trade with the Visegrád countries was greater than with China and Russia combined, and almost double the figure with France. Hungarian exports to Germany were half of French exports and surpassed Russia's exports in 2020 (ECB 2020).

\section{Unplanned changes - Unity in diversity?}

It would be interesting to examine the patterns outlined based on the experiences so far that can be useful for the future. Is the oft-cited pattern true that the euro has divided members into two groups: the southerners with recurring balance issues and the westerners with permanent balance of payments and trade surpluses? One might venture to make several statements about this.

First, in Europe, the economic, institutional and socio-cultural dividing lines do not overlap. In fact, there is currently a sort of realignment, diverting some of the traffic within the euro area in a euro area-non-euro area direction, mainly due to a dynamically growing German-V4 connection.

Partly because of this, the worries that introducing the EU later than planned would automatically place countries on the wrong side of a new dividing line in Europe do not seem warranted. A Europe of concentric circles or the emergence of a "core" and a "periphery" along the lines of the euro does not seem realistic, if only because the real structural obstacles to completing convergence are just 
as much within the "core" as outside of it. Analysts assess trends differently from several aspects, but they all agree on one thing. All scenarios should be based on the premise that the basis for the European structure is the balance between the large, dominant continental powers, where maintaining the Franco-German cooperation is an axiom, and in the political reality Italy falls almost within the same group, and although the rankings will continue to be contested for a long time, the largest players are followed by the middle of the pack with Spain and Poland. The differences are particularly huge within this core. These attract less attention than the north-south skirmishes, but they are still important. One only needs to mention the differences between Germany, France and Italy.

Of course, all members would wish to tailor the common solutions to their own experiences, traditions, philosophy and institutions, but these are different. Germany and the like-minded Netherlands, Austria, Finland within the euro area, as well as Sweden and Denmark outside the club use a market economy model based on solid public consultation, in which economic growth relies heavily on exports and the openness of the markets. By contrast, the institutional capacities and traditions of Mediterranean members rely less on planning growth strategies. The traditional main tool of addressing challenges in competitiveness is the devaluation of the currency, i.e. adjustment through the exchange rate. Compared to these, the French model is unique in that the state plays a much greater role than in the others, and economic growth is based more on domestic demand than on exports (Tokarski 2019). (It may not require such a stretch of imagination to search for the roots of the European strategic autonomy coined by Macron, adapted to the need that Europe, the domestic market for France, should be protected against external competition by environmental, fiscal and employment-based market protection measures, and also against internal competitors with improving competitiveness in goods and services, mainly from the east, on the EU's single internal market.)

\section{Attempts at managing the diversities}

As already noted, size does matter. Of course, all members are responsible for adherence to the common rules, but the responsibilities of the small, mediumsized and large countries differ as regards the negative consequences for the entire system arising from breaking the rules. What makes the operation of the system difficult is that experience has shown that adherence to the rules and responsibility are not directly correlated. It should be recalled that even if the toolkit for enforcing the fiscal rules that are so important for operating the system has been refined (Two-Pack ${ }^{11}$, Six-Pack, ${ }^{12}$ Fiscal Compact ${ }^{13}$ ), these tools have never actually been

\footnotetext{
${ }^{11}$ https://ec.europa.eu/commission/presscorner/detail/en/MEMO_13_457

12 https://ec.europa.eu/commission/presscorner/detail/en/MEMO_13_979

${ }^{13}$ https://eur-lex.europa.eu/legal-content/EN/TXT/?uri=LEGISSUM\%3Ā1403_3
} 
used. What should be an even bigger red flag: their use was considered in earnest only once, when the suspension of cohesion funds was foreseen for Hungary, which has not introduced the single currency and exerts no major spillover effects due to its size. In the famous German, France and Spanish cases, there was no political power to impose the sanctions. It remains to be seen how to consistently enforce rules in the case of large and powerful members. Therefore, it is also impossible politically in smaller and poorer countries.

If reforms cannot be enforced with punitive financial measures, the question remains how to encourage members to implement the often not very popular reforms that are expected to entail improved competitiveness and the conditions necessary for long-term, sustainable and balanced growth. This led to the calls for the so-called economic semesters.

As part of the semester, the Council offers recommendations, based on the Commission's proposal, with a qualified majority, to all countries, and implementation is also monitored. However, the practices are controversial here, too. Ever since the Juncker Commission defined itself as a political actor and has been acting like it instead of the good and innocent practice of "exchange of economic policy experiences and advice" used in the OECD, the approval of the recommendations has increasingly become politically contested, where objective expert analyses have been replaced more and more by ideological, unmeasurable debates, for example on the rule of law. Aside from this, another problem is the extent to which institutions without political responsibility can take over the role of elected governments, parliaments and decision-makers. Who can voters hold accountable for decisions that turn out to be wrong? It is difficult to force governments with a political responsibility to implement tough reforms against their own will, with the claim that the Commission's apparatus knows better what the Member State needs than its elected leaders. This is why Member States have implemented only 7 per cent of the "recommendations" in the past ten years. ${ }^{14}$

The attempts were taken to a new level by the agreement in December 2020 on the multi-year budget for 2021-2027 and the Reconstruction Fund of EUR 750 billion. In the case of the latter, the international community was concerned with the possibility of a Hungarian and Polish veto. Yet three other issues, which were just as important and may be crucial for the euro area and European integration as a whole, were also discussed. First, the issue of a separate budget for the euro area was abandoned for some time due to the pandemic and the Reconstruction Fund. The significant step that was urged so much by the French and southern countries as a step towards complementing the euro's structure was not made.

${ }^{14}$ Report by the European Commission on the implementation of the semester recommendations, 2019. https://op.europa.eu/webpub/eca/special-reports/european-semester-16-2020/en/index.html 
But there was a practical measure, which had just as much theoretical significance, although interestingly it was not taken within the framework of the euro area but of the EU-27: a decision was made on common bond issuance and thus the communitarisation of some of the debt. This is a breakthrough in meeting French and southern demands, even if it is claimed that this was a one-off, which does not create a precedent. Third, a special new situation emerged in enforcing reforms, too. The grants and preferential loans that are calculated based on the damage caused by the pandemic, and are therefore mainly geared towards the south, can only be drawn down if the beneficiary member country can present for approval a reform programme subject to phased performance and payment requirements, which, when implemented, is expected to yield structural reforms that, if upheld, will eliminate the need for further external assistance, which makes the claim that this is a one-off programme more credible. Devising, discussing, approving and especially implementing the programme will be an unprecedented institutional and also credibility challenge for all stakeholders. According to the accepted process, the "goodwill" of not only the Commission but also of the 26 other Member States will have to be obtained for the programmes. The question will be whether in a strained market situation, for example the Netherlands delays or even prevents the approval of, say, an Italian programme that would be the key to survival, or the disbursement of an upcoming instalment. Or how will the approval of a Hungarian or Polish programme by Sweden or Finland go? How will this change the decadesold practice that uncomfortable decisions are usually made by Member States without looking each other in the eye and placing the Commission in between them, and can it change it at all? How much tension will be generated by this system? Shall the process be objective and evidence based or turn into an instrument serving political or ideological objectives. These are tough questions, and the answers shall have far-reaching consequences.

\section{Conclusions}

What conclusions can be drawn from this for Hungary's euro introduction? The answers can be found in three dimensions:

- the further development of the euro area's structure,

- the impact of introducing the euro on Hungary's European policy,

- the cost-benefit calculation of the direct material effects of joining.

The structure of the euro area has come a long way since its creation. It has become able to manage a crisis, and the instruments necessary for doing so have been devised. However, the conflicts arising from the different views of the Member States, primarily regarding risk reduction and sharing have continued. 
The establishment of a fiscal union would transfer important powers from the Member States to the EU. There seems to be no sufficient political will for this, even if without it the structure remains unfinished.

It has not been proven that the euro area means a kind of higher quality and that remaining outside is certainly negative in itself, while joining it definitely entails positive effects. Structural improvements can be made outside, and even those inside can fall behind. It is not only, or not primarily, about the currency; there are winners and losers among the founders and the new members, too.

The border of the euro area does not denote a line between good and poor quality within the EU. It has already been established that the political affiliation was decided with the EU and NATO accession, and no trade diversion effect should be expected. In a wider European policy context, the question is rather what kind of Europe we would like to see in 10, 20 or 50 years, where we would feel comfortable. To put it simply: a "strong Europe based on strong members" or a federal structure where a major part of Member States competencies are exercised through common institutions. From a Hungarian perspective, even without answering this deeply political question, the integrity and level playing field of the internal market seem to be more important than the common currency. Cohesion policy should facilitate convergence, the position of less dominant countries and companies should be protected by competition rules, and the fairness of rule enforcement should not be distorted by institutional, political and/or self-interests.

The experiences so far have shown that other than the lower yields, the advantages are not automatic, neither for the founders, nor for those that joined later. There are examples of falling behind and convergence in the case of founders and those that joined later, and the same holds true for those that stayed outside. The real question is the "reformability" of the given country in a political, social and economic sense. There are cases where reform attempts are met with opposition, and also where a country can implement meaningful reforms in a relatively short period, which happened in Germany at the turn of the 2000s and after 2010 or in Latvia before and after 2010. In any case, transition countries have vast experience in this regard.

The consequences affecting the freedom of decision-making should be taken into account, as it is ultimately a question of sovereignty and also an institutional one. On the one hand, euro membership opens up new opportunities for participating in decision-making, since the decisions about the euro are taken by, understandably and rightly, the participants, and only them. This increases countries' influence over the decisions that affect them. As people say, the countries can shape the decisions that impact them rather than merely suffering the consequences. On the other hand, the option is lost to pursue an independent monetary policy that is best aligned with a country's own economic objectives and circumstances according to 
its best judgement. The single monetary policy has to take into account northern, southern, eastern and western considerations, all at the same time. This also confirms that the introduction of the single currency should be considered only when it can be assumed with reasonable certainty that there are no more unique aspects, for example related to convergence or lower competitiveness, that would warrant, or even require, autonomy in monetary policy.

The lessons and conclusions are not straightforward.

Further research should be conducted to see how realistic the assumption is that the convergence process of a converging country requires adjustment through the exchange rate, because otherwise it would experience other negative consequences, for instance a deterioration in its trade balance or a growth or employment sacrifice. Or precisely the opposite, a fixed exchange rate is necessary to provide normative pressure in competitiveness that is vital for structural changes and increasing value added. It is interesting to see the experiences of Bulgaria and the Baltic countries with the "currency board", i.e. an exchange rate pegged to the euro.

It has been established that a structural change can mean success outside, and countries can fall behind within the club if they fail to adjust to the challenges. Euro membership may be a huge advantage to the vulnerable in a great turmoil. Experience shows that normally the very strong and the competitive can acquire surplus resources due to the euro, while vulnerability can often lead to losses.

It all depends on value choices, self-confidence and the perception of various risks. This paper advocates the following "stance".

The introduction of the euro should not be considered the fixed point to which Hungary's vision should be aligned. Instead, the country's vision should be developed, and the country should examine how the introduction of the euro fits into that. This paper argues that what we will see is that a liveable, good country requires preparation for the changes that adjust the factors of success. This calls for fine-tuning human resources, the physical infrastructure and the structure of the economy as a whole to meet the technological and other challenges. This is what will make countries competitive. Hungary should assess the horizon at which it can achieve this. Meanwhile, it should be borne in mind that the shocks experienced by the world in 2008-2009 and now, during the pandemic, will not go away. Realistically, no crisis-free periods longer than 10-15 years can be expected. In times of crises, a safety net tried and tested in crisis management and yield reduction may be needed. People should also be aware that the introduction of the euro not only means a safety net but also the narrowing of the nation's room for manoeuvre. The question is whether the country believes that it can implement the necessary changes better and faster alone, rather than as part of a system 
with numerous participants. Furthermore, time is of the essence. If the external vulnerabilities can be reduced rapidly, the chance of success while staying outside is greater, but if not, it is better to choose the "common roof" that provides greater security. In simple terms, if the country thinks that debt levels can be significantly and steadily reduced while implementing the structural reforms necessary for boosting competitiveness, introduction of the euro should be postponed until the current uncertainties have cleared up. But if this does not seem to be realistic, an accession date as soon as possible should be set, and it should be viewed as a compass that guides the country into a safe haven in due course. Although this latter option seems to be easier, the author argues that in the long run, the more arduous, first way is safer.

\section{References}

Acocella, N. (2020): The European Monetary Union - Europe at the Crossroads. Cambridge University Press. https://doi.org/10.1017/9781108892858

Alcidi, C. - Ferrer, J.N. - Di Salvo, M. - Musmeci, R. - Pilati, M. (2018): Income convergence in the EU: A tale of two speeds. Commentary, CEPS. https://www.ceps.eu/wp-content/ uploads/2018/01/ConvergencePDF.pdf. Downloaded: 5 May 2021.

Bongardt, A. - Hefeker, C. - Hermann, C. - Torres, F. - Wunsch, P. (2013): Convergence in the EU. Intereconomics - Review of European Economic Policy, 48(2): 72-92. https://doi. org/10.1007/s10272-013-0448-9

Bordo, M. - Jonung, L. (1997): The history of monetary regimes - some lessons for Sweden and the EMU. Swedish Economic Policy Review, 1997/4: 285-358. https://www. government.se/contentassets/04510354cfc64675bb7ac0557c26374f/michael-d.-bordo-lars-jonung-the-history-of-monetary-regimes---some-lessons-for-sweden-and-the-emu. Downloaded: 5 May 2021.

ECB (2020): Convergence Report. European Central Bank. https://www.ecb.europa.eu/pub/ convergence/html/ecb.cr202006 9fefc8d4c0.en.html. Downloaded: 5 May 2021.

Erhart, S. (2021): Ready or not? Constructing the Monetary Union Readiness Index. JRC Technical Report, European Commission. https://op.europa.eu/en/publication-detail/-/ publication/4d08a9bf-6504-11eb-aeb5-01aa75ed71a1. Downloaded: 5 May 2021.

Franks, J.R. - Barkbu, B.B. - Blavy, R. - Oman, W. - Schoelermann, H. (2018): Economic Convergence in the Euro Area: Coming Together or Drifting Apart? IMF Working paper, WP/18/10, International Monetary Fund. https://doi.org/10.5089/9781484338490.001 
HCSO (2020): Helyzetkép a külkereskedelemröl, 2019 (The current situation of external trade, 2019). Hungarian Central Statistical Office. https://www.ksh.hu/docs/hun/xftp/idoszaki/ kulker/2019/index.html. Downloaded: 5 May 2021.

Tokarski, P. (2019): Divergence and Diversity in the Euro Area - The Case of Germany, France and Italy. SWP Research Paper 2019/RP 06, German Institute for International and Security Affairs. https://doi.org/10.18449/2019RP06

Virág, B. (ed.) (2020): Fenntartható felzárkózás euróval. Hogyan újitsuk meg a maastrichti kritériumokat? (Long-term sustainability and the euro - how to rethink the Maastricht criteria?). Magyar Nemzeti Bank. 